\title{
Challenges to Teaching and Learning Using MOOC
}

\author{
Norfarahi Zulkifli, Mohd Isa Hamzah, Nur Hazeleen Bashah \\ Faculty of Education, Universiti Kebangsaan Malaysia, Bangi, Malaysia \\ Email: farahijpa@gmail.com
}

How to cite this paper: Zulkifli, N., Isa Hamzah, M., \& Bashah, N. H. (2020). Challenges to Teaching and Learning Using MOOC. Creative Education, 11, 197-205. https://doi.org/10.4236/ce.2020.113014

Received: December 25, 2019

Accepted: March 6, 2020

Published: March 9, 2020

Copyright (c) 2020 by author(s) and Scientific Research Publishing Inc. This work is licensed under the Creative Commons Attribution International License (CC BY 4.0).

http://creativecommons.org/licenses/by/4.0/

\begin{abstract}
The Malaysian Education Development Plan (PPPM) 2015-2025 (Higher Education) strongly emphasizes the use of information technology and the transformation of the delivery of teaching and learning processes (T \& L). The plan places the ninth shift in the global online learning which is intended to transform the education system by leveraging information technology in improving the quality of learning in Malaysia. This is in line with Education 4.0 which highlights the 21 st century skills that are so important to be applied in education. Massive Open Online Courses (MOOCs) are a platform introduced as a new approach to the T \& L process. Although MOOCs have been found to improve teaching and increase student engagement, many previous studies have shown that students' readiness to use MOOCs is still at a moderate level. Therefore, this study was conducted to identify the major barriers to the use of MOOCs at one polytechnic in the Southern Zone. This quantitative study was conducted by administering the questionnaire to 213 students for feedback. Data were collected using a 1 to 5 Likert scale and analyzed using Statistical Package For Social Science (SPSS) by measuring the frequency and percentages. The alpha value of the questionnaire was, $\alpha=0.887$. The findings showed that internet/Wi-Fi coverage sources are a major obstacle to using MOOCs within the classroom even though students are committed and motivated towards using MOOCs.
\end{abstract}

\section{Keywords}

Massive Open Online Course (MOOC), Educational Technology, Challenges

\section{Introduction}

In line with the rapid development of education today, new technologies are emerging providing a variety of tools for educators to improve the $\mathrm{T} \& \mathrm{~L}$ processes. Education technology also opens new opportunities and platforms in 
improving learning, transforming the delivery of knowledge, enriching creativity in the educational process and even changing the education ecosystem in Malaysia. The use of technology has indeed given new and more effective implications in education and at the same time contributing to the smoothness of education (Nordin \& Ngau, 2009). This stream of change demands a rapid transformation in all aspects of the educational process, whether from the curriculum, communication, creativity, teaching methods, learning styles, teaching aids or teaching design using technology approaches. This statement is also consistent with Spector (2012) who stated that the integration of technology in education involves the discipline of a knowledge application aimed at facilitating the teaching, learning and achievement process.

Technical Vocational Education and Training, known as TVET is catching up with the latest trends in the development of current technology to meet the aspirations and direction of education in Malaysia. This is in line with PPPM (PT) 2015-2025 under the 4th shift in Quality TVET Graduates, the 9th shift in Global Online Learning and the 10th shift in Higher Education Transformation. Those fundamental require a significant leap in technology-based for quality improvement in teaching and learning methods which are tailored to all students. The emergence of MOOC as the latest approach in Malaysia has become the Ministry's priority agenda under the 9th shift: Globalized Online Learning in the PPPM (PT) 2015-2025 (http://www.mohe.gov.my). MOOC is offered to students locally and abroad (http://jpt.mohe.gov.my). In Malaysia, MOOC was first launched in September 2015 and is hoped to enhance the quality and accessibility of higher education. At that time, 450 MOOC courses were offered by public universities, private universities, polytechnics and community colleges (https://www.bharian.com.my, September 26, 2017). According to Marshal (2014) the concept of MOOCs has explicitly reviewed the online learning methods in higher Learning Institution. MOOC has evolved and became the latest approach to online learning that offers students' learning regardless of the place, time and environment. MOOC is favored as a global-based online learning that is capable in capturing students in a large-scale capacity (Nordin, Norman, \& Embi, 2015). MOOC is a medium of teaching that reforms different forms of teaching. It is also a complement to the lifelong learning environment and it has become an initiative in the 21st century technology-based education (Haron, et.al, 2019). MOOC has become a teaching innovation and it has gained serious attention in academic circles across various fields such as engineering, languages, Islamic education and many more, locally and abroad (Zainuddin, et al. 2019, Zainuddin \& Rosilawati, 2018, Zulkifli \& Daud, 2017). The use of MOOC also has impacted the students' lives on all major aspects such as academic potential, reinforcement, achievement, motivation, interaction and self confidence (Dziuban et al. 2018, Swigart \& Zhan, 2016, Bucovetchi et al., 2016, Hossain et al. 2015).

Polytechnic as the TVET institution has begun to step in by integrating education technology into the $t \& l$ processes with the use of MOOC as a teaching 
approach in most courses offered. For example, in the Department of General Studies at one polytechnic in the Southern Zone, MOOC was developed by lecturers for courses such as DUE3012 Communicative English 3, DUB1012 Malaysian Studies and DUA6022 Islamic Communication and Broadcasting which offer students in accessing to learning materials, assignments and activities. There are many benefits of using MOOCs that attract both academia and students. According to Cole \& Timmerman (2015), MOOC allows students to interact with course partners from diverse educational backgrounds and to share their thoughts and ideas. Adzhar et al. (2017) described online courses, flexible design and interactivity development are elements of MOOC that contribute to its greater usage.

For instance, the study of Bucovetchi et al. (2016) found that students are ready to use MOOC as an online learning platform to enhance their knowledge and skills. Daud et al. (2017) showed in their study that graduate students at the Faculty of Education of National University of Malaysia (UKM) have high readiness to use MOOC as a new learning platform. The use of MOOCs in this system is an integrated technology effort to ensure students receive online information and learning materials online. This is to ensure MOOC is one of the main mediums that connect lecturers and students in all forms of space. There are various implications for the implementation of MOOCs and technologies in education including enhancing communication, nurturing communities and improving student achievement itself (Anderson et al., 2011). More recently, Hashim, H. et al. (2019) found that students are prepared and able to utilize MOOC in their learning.

Although many previous studies have looked at the benefits of using MOOC and its impact on the $\mathrm{T} \& \mathrm{~L}$ processes, researchers want to see if there are any problems or challenges in the use of MOOC. Paul \& Hillage (2001) in their study stated that the benefits of e-learning are not enjoyed by all organizations. Jayakumar (2014) stated that there are some other issues faced by students such as language skills and technical support. The technical problem is due to server error, slow network connection, etc. The students are not able to do the task assigned to them due to the technical network problems. Atiaja and Proenza (2016) also identified that teaching, technological and organizational aspects of the organization are also problems and challenges in the use of MOOC in higher learning institutions. According to Siti Fatimah \& Siti Hasmiza (2018), students are found to be modest and less motivated to use MOOC as MOOC is only applicable to certain courses. Nurul Ain and Liza (2018) in their study showed that MOOC readiness for Business Operations Certificate students is at a moderate level.

At present, the use of MOOC at one polytechnic in the Southern Zone is relatively new and has not been comprehensively used in all courses offered. Therefore, this study seeks to identify the major challenges in teaching and learning using MOOC in polytechnic. This will assist the lecturers in shaping and 
achieving a more meaningful teaching process for the students as well as helping the institution to improve various aspects in an effort to provide more conducive t \& 1 environment to students.

\section{Methodology}

Descriptive survey studies were conducted in this study by using questionnaire as a research instrument to obtain data and information. According to Creswell (2005) survey design is a procedure in quantitative research in which the researcher conducts a survey of the sample or the entire population. A total of 213 students for December 2018 session were randomly selected as respondents in this study representing all academic departments at one polytechnic in the Southern Zone. The instrument of the study used a questionnaire form which was adapted from the study of Daud, M. Y. et al. (2017). The data were collected using a 1 to 5 Likert scale from strongly disagree to strongly agree. Scale 5 for "strongly agree", scale 4 for "agree”, scale 3 for "uncertain”, scale 2 for "disagree" and scale 1 for "strongly disagree". Data were analyzed using the Statistical Package for Social Science (SPSS) program by looking at frequency and percentages.

\section{Findings and Discussion}

This section presents the findings from the data collection in the distributed questionnaire. The findings are divided into two parts related to demographics of the respondents and the challenges to teaching and learning using MOOC.

\subsection{Demographic}

The respondents' demographics in this study refer to their gender, age category, level of study and department. Table 1 showed that 213 respondents were involved in this study. A total of 116 respondents were male or $54.7 \%$ and 96 or $45.3 \%$ were female respondents. It is found that the number of male respondents is greater than the female respondents.

Table 2 showed the age categories of respondents. A total of 141 people or $66.2 \%$ of respondents were under 21,71 people or $33.3 \%$ of respondents aged 21 to 5 and 1 person or $0.5 \%$ of respondents aged 26 to 30 . This indicated that the majority of respondents were under the age of 21 and no respondents were listed in the age group of 26 and above.

The level of study at this institution started from semester 1 to semester 6 and the questionnaire were distributed randomly to the students. Table 3 showed the

Table 1. Gender.

\begin{tabular}{ccc}
\hline Gender & Frequency (N) & Percentage (\%) \\
\hline Male & 117 & 54.9 \\
Female & 96 & 45.1 \\
Total & 213 & 100 \\
\hline
\end{tabular}


Table 2. Age.

\begin{tabular}{ccc}
\hline Age & Frequency $(\mathrm{N})$ & Percentage $(\%)$ \\
\hline Below 21 years & 141 & 66.2 \\
21 to 25 years & 71 & 33.3 \\
26 to 30 years & 1 & 0.5 \\
Above 30 years & 0 & 0 \\
Total & 213 & 100 \\
\hline
\end{tabular}

Table 3. Level of study.

\begin{tabular}{ccc}
\hline Semester & Frequency (N) & Percentage (\%) \\
\hline Semester 1 & 78 & 36.6 \\
Semester 2 & 1 & 0.5 \\
Semester 3 & 38 & 17.8 \\
Semester 4 & 24 & 11.3 \\
Semester 5 & 70 & 32.9 \\
Semester 6 & 2 & 0.9 \\
Total & 213 & 100 \\
\hline
\end{tabular}

level of study of the respondents. 78 respondents or $36.6 \%$ of Semester 1, 1 respondent or $0.5 \%$ of Semester 2 and 38 respondents or $17.8 \%$ of Semester 3. There were 24 respondents or $11.3 \%$ of Semester 4,70 respondents or $32.9 \%$ of Semester 5 and 2 respondents or $0.9 \%$ of Semester 6 . This finding clearly showed that the majority of respondents are under the age of 21 .

The respondents consisted of students in 4 academic departments in this institution. Table 4 shows 58 respondents or $27.2 \%$ of the Department of Design and Visual Communication (JRKV), 49 respondents or 23\% of the Department of Tourism and Hospitality (JPH), 59 respondents or $27.7 \%$ of the Department of Mechanical Engineering (JKM) and 47 respondents or $22.1 \%$ of the Department of Electrical Engineering (JKE).

\subsection{Challenges to Teaching and Learning Using MOOC}

Table 5 represents the Likert scale from scale 1 to scale 5 which showed that obstacles exist in the use of MOOC during the t\&l processes at one polytechnic in the Southern Zone which is seen in terms of technology, organization, motivation, technology, learning style and personality. There are eight (8) types of challenges identified namely internet/Wi-Fi coverage sources, understanding of MOOC usage, MOOC usage equipment, student commitment, student motivation, MOOC materials, allocation of grades and course offerings in MOOC.

The highest items are viewed from the item's point of view as the percentage of the scale agrees and the scale strongly agrees. The results showed that Item 1 had the highest agreeable percentage of $63.4 \%$ with frequency of 135 while Item 
Table 4. Departments.

\begin{tabular}{ccc}
\hline Department & Frequency $(\mathrm{N})$ & Percentage $(\%)$ \\
\hline Design and Visual Communication & 58 & 27.2 \\
Tourism and Hospitality & 49 & 23 \\
Mechanical Engineering & 59 & 27.7 \\
Electrical Engineering & 47 & 22.1 \\
Total & 213 & 100 \\
\hline
\end{tabular}

Table 5. Challenges to teaching and learning using MOOC.

\begin{tabular}{lccccc}
\hline \multicolumn{1}{c}{ Item } & $\mathrm{SD}$ & $\mathrm{D}$ & $\mathrm{UC}$ & $\mathrm{A}$ & $\mathrm{SA}$ \\
& $\%$ & $\%$ & $\%$ & $\%$ & $\%$ \\
& $(\mathrm{~N})$ & $(\mathrm{N})$ & $(\mathrm{N})$ & $(\mathrm{N})$ & $(\mathrm{N})$ \\
\hline \multirow{2}{*}{ 1) Low internet/Wi-Fi coverage source } & 2.8 & 6.1 & 27.7 & 32.4 & 31 \\
& $(6)$ & $(13)$ & $(59)$ & $(69)$ & $(66)$ \\
2) Lack of understanding in using MOOC & 10.3 & 31.5 & 26.3 & 22.5 & 9.4 \\
& $(22)$ & $(67)$ & $(56)$ & $(48)$ & $(20)$ \\
3) Incomplete equipment in using MOOC & 12.7 & 29.6 & 31.9 & 18.3 & 7.5 \\
& $(27)$ & $(63)$ & $(68)$ & $(39)$ & $(16)$ \\
4) Unable to fully commit online & 8.9 & 24.9 & 32.9 & 23 & 10.3 \\
& $(19)$ & $(53)$ & $(70)$ & $(49)$ & $(22)$ \\
5) There is no motivation for joining the t\&l in & 19.2 & 27.7 & 33.3 & 13.6 & 6.1 \\
MOOC & $(41)$ & $(59)$ & $(71)$ & $(29)$ & $(13)$ \\
6) The material in the MOOC course is not & 24.9 & 29.1 & 22.5 & 16.4 & 7 \\
interesting/boring & $(53)$ & $(62)$ & $(48)$ & $(35)$ & $(15)$ \\
7) There is no standard allocation of scores in the & 14.1 & 23.9 & 39.4 & 17.8 & 4.7 \\
MOOC & $(30)$ & $(51)$ & $(84)$ & $(38)$ & $(10)$ \\
& 7.5 & 13.1 & 43.7 & 27.2 & 8.5 \\
8) Not all courses are offered in MOOC & $(16)$ & $(28)$ & $(93)$ & $(58)$ & $(18)$ \\
\hline
\end{tabular}

5 had the lowest agreeable rate of $19.7 \%$ with frequency of 42 . Item 8 related to course offerings in MOOC was the second highest barrier factor of $35.7 \%$ and frequency of 76. Item 4 related to student commitment was the third highest factor with a value of $33.3 \%$ and frequency 71 . Next, item 2 related to student understanding became the fourth barrier factor with a value of $31.9 \%$ and frequency of 68 . The fifth barrier factor were related to equipment which fall under item 3 with $25.8 \%$ and frequency of 55. Item 6 related to the MOOC course material was the ninth barrier factor with $23.4 \%$ and frequency of 50 . The scoring aspect in item 7 was the seventh barrier factor with $22.5 \%$ and frequency of 48 . Content limitation and the allocation of student engagement rates is also an obstruction in MOOC (Atiaja \& Proenza 2016).

Based on the findings of this study, it is clear that the major challenges to teaching and learning using MOOC at one polytechnic in the Southern Zone is a low internet or Wi-Fi coverage. The source of Wi-Fi coverage at the institution is one of the gears that is emphasized because Wi-Fi coverage is the main facility that students need throughout their studies in the institution. This is in line with the National e-Learning Policy 2.0 (DePAN 2.0) which also focuses on the use 
and improvement of Wi-Fi coverage across Higher Learning Institutions with 90\% Wi-Fi coverage in Phase 2 (2016-2020) and 100\% of Wi-Fi coverage for students in Phase 3. Whereas students' motivation is not an obstacle as it scores the lowest percentage. MOOCs are found to have elements that help improve students' readiness in terms of learning, easy to use, clear and easy to understand. There are various implications for the implementation of MOOCs and technologies in education including enhancing communication, nurturing communities and improving student achievement itself (Anderson et al., 2011). This is in line with Ismail et al. (2018) who stated that the use of MOOC can improve performance, make learning more attractive and that MOOC can improve existing teaching aids.

However, there are other barriers discussed in previous studies that can be given a fair attention. MOOC participants who are less skilled in the use of technology have become a great challenge to the facilitators and this has been highlighted in a study by Ramirez, M. et al. (2014). Some other issues identified by Motzo \& Proudfoot (2017) were related to moderating discussion, responding to queries, task design for collaborative practices, cultural issue, sensitivity awareness and retention issue. Chea (2016) found two main challenges in MOOC are the high non-completion rates (high drop-out rate) and the pressure on institutions in reducing costs. This polemic requires the attention of lecturers to become more competent in digital and technology. On the contrary, institutions are challenged with maintaining the relevance of courses offered using MOOC. Therefore, the lecturers should take note of the importance of this element to constantly improve the MOOC platform that has been developed to make an impact in the $\mathrm{T} \& \mathrm{~L}$ processes.

\section{Conclusion}

The use of MOOC in the teaching and learning process has undeniably brought a positive impact on education especially in higher education. With the rapid growth of the digital world and the development of the latest technology in education, new alternatives and innovations in the process of delivering knowledge are readily accepted by students and educators despite obstacles and challenges in some respects. Although there are findings showed that some of the factors are considered as an obstruction to the use of MOOC in the teaching and learning, and the main factor is low source of Wi-Fi coverage, the lecturers can still take the initiative to devise the best strategies in their teaching needs to maximize the use of MOOC in the teaching and learning process. On the other hand, institutions need to constantly improve their Wi-Fi coverage facilities to meet the needs of students for them to cope up with the challenges and efforts in developing and equipping themselves for the 21st century teaching. Therefore, lecturers should take a serious note on the importance of this element to constantly improve the MOOC platform that has been developed to make an impact in the teaching and learning process. 


\section{Conflicts of Interest}

The authors declare no conflicts of interest regarding the publication of this paper.

\section{References}

Adzhar, H., Khalid, F., \& Karim, A. A. (2017). Penggunaan Massive Open Online Course (MOOC) sebagai Kaedah Pembelajaran Baharu. In D. R. M. Rosly, N. A. Razali, \& N. A. Jamilluddin (Eds.), Pembelajaran Abad ke-21: Trend Integrasi Teknologi (pp. 179-188). Bangi: Fakulti Pendidikan UKM.

Ain, N., \& Liza, R. (2018). Kesediaan Penggunaan Massive Open Online Course (MOOC) Dalam Kalangan Pelajar Sijil Pengoperasian Perniagaan Kolej Komuniti Ledang. In International Prosiding Conference on Global Education VI (ICGE VI) (pp. 1932-1942). Anjuran akulti Pendidikan (UKM), Bangi \& Universitas Ekasakti Padang (UNES), Indonesia dengan kerjasama Fakulti Pendidikan (USM), Pulau Pinang \& Politeknik Seberang Perai (PSP). Pulau Pinang pada 8 Mei 9 Mei 2018.

Anderson, E. W., Potter, K. C., Matzen, L. E., Shepherd, J. F., Preston, G. A., \& Silva, C. T. (2011). A User Study of Visualization Effectiveness Using EEG and Cognitive Load. Computer Graphics Forum, 30, 791-800. https://doi.org/10.1111/j.1467-8659.2011.01928.x

Atiaja, L., \& Proenza, R. (2016). Moocs: Problems and Challenges in Higher Education. In International Conference on Advances in Education, Teaching \& Technology (pp. 82-88). Canada: Unique Conference Canada.

Bucovetchi, O., Stanciu, R. D., \& Simion, C. P. (2016). Study on Designing a Curriculum Suitable for MOOC Platforms Starting out the Romanian Students' Expectations. Procedia-Social and Behavioral Sciences, 22, 1135-1141.

https://doi.org/10.1016/j.protcy.2016.01.160

Chea, C. C. (2016). Benefits and Challenges of Massive Open Online Courses. ASEAN Journal of Open Distance Learning, 8, 16-23.

Cole, A. W., \& Timmerman, C. E. (2015). What Do Current College Students Think about MOOCs? MERLOT Journal of Online Learning and Teaching, 11, 188-201.

Creswell, J. W. (2005). Educational Research Planning, Conducting, and Evaluating Quantitative and Qualitative Research. Upper Saddle River, NJ: Pearson.

Daud, M. Y., Zulkifli, F. N., Rahman, M. J. A., \& Khalid, F. (2017). Kesediaan Pelajar Siswazah Menggunakan Mooc Dalam Pengajaran Dan Pembelajaran. Prosiding Seminar Pendidikan Serantau ke-VIII 2017. Anjuran Fakulti Pendidikan, Universiti Kebangsaan Malaysia \& Fakultas Keguruan \& Ilmu Pendidikan, Universitas Riau.

Dziuban, C., Graham, C. R., Moskal, P. D., Norberg, A., \& Sicilia, N. (2018). Blended Learning: The New Normal and Emerging Technologies. International Journal of Educational Technology in Higher Education, 15, 1-16.

https://doi.org/10.1186/s41239-017-0087-5

Haron, H., Hussin, S., Yusof, A. R. M., \& Yusof, H. (2019). MOOC Initiative: A Technology Enhanced Learning in 21 Century at Higher Learning Institution. Journal of Information System and Technology Management, 4, 26-33. https://doi.org/10.35631/jistm.414003

Hashim, H. U., Rusli, R., Yunus, M. Md., \& Hashim, H. (2019). Are Malaysian University Students "MOOCs-Ready"? Creative Education, 10, 2540-2547.

https://doi.org/10.4236/ce.2019.1012181

Ismail, M. E., Hashim, S., Ismail, I. M., Ismail, A., Razali, N., Mat Daud, K. A., \& 
Khairudin, M. (2018). The Use of Massive Open Online Course (MOOC) among Vocational Students. Journal of Nusantara Studies (JONUS), 3, 30.

https://doi.org/10.24200/jonus.vol3iss1pp30-41

Jayakumar, S. (2014). Educational Paradigm Shift: Are We Ready to Adopt MOOC? International Journal of Emerging Technologies in Learning, 9, 50-55.

https://doi.org/10.3991/ijet.v9i4.3756

Kursus dalam talian di Malaysia jadi pilihan (2017). Berita Harian. https://www.bharian.com.my

Marshal, S. (2014). MOOCs: Emerging Research Exploring the Ethical Implications of MOOCs. Journal Distance Education, 35, 250-262.

https://doi.org/10.1080/01587919.2014.917706

Massive Open Online Course (MOOC) (2018). http://jpt.mohe.gov.my

Motzo, A., \& Proudfoot, A. (2017). MOOCs for Language Learning: Opportunities and Challenges: The Case of the Open University Italian Beginners' MOOCs. In Q. Kan, \& S. Bax (Eds.), Beyond the Language Classroom: Researching MOOCs and Other Innovations (pp. 85-97). Research-Publishing.net. https://doi.org/10.14705/rpnet.2017.mooc2016.673

Nordin, N. M., \& Ngau, C. H. (2009). Pembangunan dan penilaian bahan pengajaran dan pembelajaran berasaskan web: Webquest bagi mata pelajaran ICT. Jurnal Pendidikan Malaysia, 34, 111-129.

Nordin, N., Norman, H., \& Embi, M. (2015). Technology Acceptance of Massive Open Online Courses in Malaysia. Malaysian Journal of Distance Education, 17, 1-16. https://doi.org/10.21315/mjde2015.17.2.1

Ramirez, M. S., Rivera, N., \& Garcia, A. (2014). Mooc Learning. Challenges and Opportunities of Using Team Teaching. In ICERI 2014 Proceedings (pp. 5751-5756). Spain: IATED.

Spector, J. M. (2012). Foundations of Educational Technology. New York: Routledge.

Swigart, V., \& Zhan, L. (2016). Digital Resources for Nursing Education: Open Courseware and Massive Open Online Courses. International Journal of Nursing Sciences, 3, 307-313. https://doi.org/10.1016/j.ijnss.2016.07.003

Zainuddin, G., Danuri, M. S. N., Ali, A. M., Ahmad, M. I., Sokri, N. E. A., Jaffar, M. N., Ramlan, S. R., Anshar, K. B., Ismail, I. M., \& Hashim, H. (2019). A Systematic Literature Review on Massive Open Online Course for Language Learning. Creative Education, 10, 3195-3204. https://doi.org/10.4236/ce.2019.1012243

Zulkifli, F. N., \& Daud, M. Y. (2017). Transformasi pendidikan: Isu dan cabaran pendidikan abad ke-21 melalui aplikasi massive open online courses (MOOC) di Malaysia. In Simposium Pendidikan diPeribadikan: Perspektif Risalah An-Nur (pp. 99-106). Anjuran Universiti Kebangsaan Malaysia di Akademi Kepimpinan Pengajian Tnngi (AKEPT). 